DOI: $\underline{10.7242 / 2658-705 X / 2019.2 .8}$

УДК $39(397.4)$

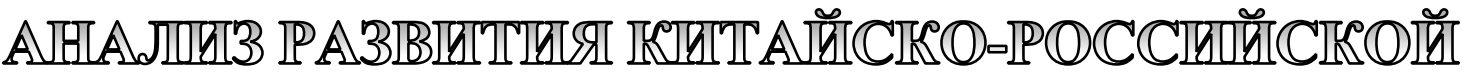

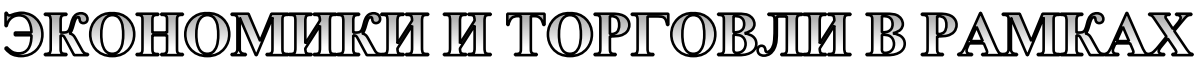

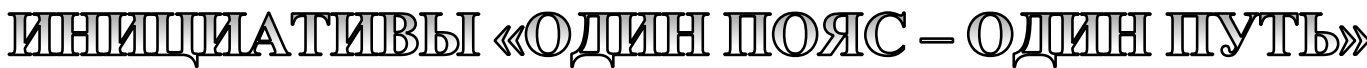

\author{
Ли Хунъюй, Китайский нефтяной университет
}

«Экономический пояс Нового Шелкового пути» и «Морской Шелковый путь XXI века», объединенные кратким названием «Один пояс - один путь», представляют собой совместный проект экономического развития Китая и его стран-соседей, являющихся одновременно его партнерами. На фоне улучшения мировой экономики китайская экономика вступает в новое нормальное состояние, в то время как российская экономика на текущий момент обладает нерациональной экономической структурой. В данной статье анализируется положительное влияние инициативы «Один пояс - один путь» на устойчивое развитие Китая и России в области экономики, культурного обмена, торговли (например трансграничной интернет-торговли). Отмечается, что, выбрав в качестве отправной точки инициативу «Один пояс - один путь», обе стороны должны преследовать общие цели, укреплять экономическое сотрудничество на взаимовыгодных условиях и совместными усилиями достигать нового развития.

Ключевые слова: конщепция «Один пояс - один путь», Китай, Россия, экономика и торговля.

В сентябре 2013 года председатель КНР Си Цзиньпин выдвинул инициативу по созданию проектов «Экономический пояс Нового Шелкового пути» и «Морской Шелковый путь XXI века» $[13$, с. 8$]$. В это же время некоторые российские ученые были обеспокоены мыслью о том, что новый проект планирует конкурировать с Евразийским экономическим союзом, и испытывали сомнения. Однако с достаточно быстрым развитием дружеских отношений между Китаем и Россией и устойчивым продвижением концепции взаимной выгоды инициатива «Один пояс - один путь» все больше и больше уделяет внимание различным социальным кругам российского общества. Проект «Один пояс - один путь» охватывает страны Азии и Европы, а также неконтинентальные страны. Благодаря сотрудничеству и совместным усилиям всех стран восточноазиатские и европейские экономические круги, расположенные на двух сторонах материка, становятся близки к развивающимся странам с огромным потенциалом экономического развития [6]. Для Китая и России связь между Евразийским экономическим союзом и инициативой «Один пояс - один путь» не только имеет стратегическое значение для геополитической стабильности, но и играет важную роль в улучшении инфраструктуры, создании сети воздушного, водного и наземного транспорта, расширении инвестиций и торговли. Проект дает импульс высокому развитию двустороннего торгово-экономического сотрудничества между Китаем и Россией. 


\section{Анализ развития китайской и российской экономики и торговли}

С начала перестройки в России наблюдается постепенное развитие экономических и торговых отношений между двумя странами. В декабре 1992 года представители России и Китая подписали в Пекине «Соглашение между Правительством Российской Федерации и Правительством Китайской Народной Республики о культурном сотрудничестве» [12], и в дальнейшем китайско-российские отношения получили развитие в рамках партнерства. Многолетние совместные усилия привели к тому, что отношения между двумя странами вышли на новый этап развития. Подписанный в 2001 году Китайско-российский «Договор о добрососедстве, дружбе и сотрудничестве между Китаем и Россией» [1] ознаменовал создание нового стратегического партнерства и сотрудничества. За три года (2001-2004 гг.) годовой объем торговли увеличился более чем на $100 \%$, создав новый рекорд в истории. С того времени объем двусторонней торговли продолжает расти. В 2014 году, на фоне проекта «Один пояс - один путь», объем двусторонней торговли между Китаем и Россией увеличился до 88,4 млрд. долларов США [16, с. 100]. Китай и Россия проявили свои преимущества и способствовали взаимной выгоде и беспроигрышным результатам.

Китай, как наиболее густонаселенная страна с большим количеством трудовых ресурсов, предоставил России текстиль, электронное оборудование и другие трудоемкие продукты. Россия, как страна, богатая ресурсами, поставляет в Китай древесину, минералы и нефть. Подобное сотрудничество восполняет соответствующие слабые стороны обеих стран и обеспечивает глубокую взаимную выгоду. В связи с этим в 2014 году президент Российской Федерации В.В. Путин во время государственного визита в Китай подписал соглашение о сотрудничестве с Кита- ем, в котором говорится, что Китай в полной мере рассмотрел интересы России в инициативе «Один пояс - один путь» [9]. В 2015 и 2017 году, когда председатель КНР Си Цзиньпин посещал Россию, В.В. Путин вновь обратил внимание на то, что проект «Один пояс - один путь» и Азиатско-европейский экономический союз полностью соответствуют запросам своего времени, а также объявил новый этап двустороннего взаимовыгодного сотрудничества между Китаем и Россией [5]. С 2018 года Россия рассматривает Китай в качестве приоритетной страныкредитора. Тесное финансовое сотрудничество между Китаем и Россией способствует дальнейшему развитию экономики и торговли на основе взаимовыгодного обмена между двумя государствами.

Указанные выше данные демонстрируют, что экономическое развитие и взаимовыгодное сотрудничество между двумя странами имеет тенденцию развития в прошлом и отличную перспективу роста в будущем под влиянием инициативы «Один пояс - один путь».

Частые тесные экономические связи между Китаем и Россией, имеющие политический фундамент, будут и впредь способствовать экономическим и торговым обменам между двумя странами. История показывает, что, хотя различий в китайско-российской политической идеологии в настоящий период не меньше, чем в период холодной войны, считается, что в наше время китайско-российские отношения являются наиболее крепкими; в то же время, хотя китайско-американская политическая идеологическая конкуренция является достаточно продолжительной, однако китайско-американские отношения демонстрируют волнообразную тенденцию сменяющих друг друга напряжения и разрядки.

Если в ближайшие несколько лет ввести дополнительный приток капитала 
в юанях на российский рынок, то этот шаг будет не только содействовать китайской стратегии интернационализации юаня, но и стимулировать недооцененный российский малый и средний бизнес [8, с. 52-59]. В настоящее время китайско-российские отношения вступили в лучший исторический период: две страны имеют не только географические преимущества, но и дополнительные преимущества в строительстве инфраструктуры, освоении ресурсов, в сфере высоких технологий, военной и других областях. Эти преимущества будут способствовать экономическому процветанию и взаимной выгоде обеих сторон в контексте нового витка мировой истории, а также постоянно укреплять сотрудничество и поддерживать друг друга в политике.

Помимо этого, общая цель проекта «Один пояс - один путь» и Евразийского экономического союза будет и впредь способствовать переходу китайско-российского экономического и торгового сотрудничества на новый уровень развития. В 2015 году был официально создан Евразийский экономический союз во главе с Россией, целью которого является содействие свободному потоку средств, товаров и рабочей силы между государствами-членами союза, а также формирование более широкого рынка (175 млн человек) [4, с. 21]. Будь то «Совместное заявление о строительстве Экономического пояса
Шелкового пути и о строительстве Евразийского экономического союза» [7], подписанное в 2015 году, или «Соглашение об экономическом и торговом сотрудничестве между Китайской Народной Республикой и Евразийским экономическим союзом», подписанное в 2018 году [15], китайская сторона активно заявляет, что она готова повысить уровень упрощения процедур торговли, чтобы еще больше снизить нетарифные торговые барьеры и создать хорошие условия для промышленного развития, а также содействовать глубокому развитию экономики и торговли между Китаем и государствами-членами Евразийского экономического союза.

Сопоставляя перспективы развития «Одного пояса - одного пути» и Евразийского экономического союза, можно обнаружить, что между двумя основными концепциями существует взаимосвязь. В то же время страны-члены Евразийского экономического союза являются важными партнерами в разработке проекта «Один пояс один путь». Поэтому китайская сторона четко сформулировала в «Соглашении об экономическом и торговом сотрудничестве между Китайской Народной Республикой и Евразийским экономическим союзом», что Китай готов работать со своими партнерами и предоставлять им гарантии поддержки экономического и торгового сотрудничества между двумя сторонами для взаимной выгоды обеих сторон.

\section{Влияние инициативы «Один пояс - один путь» на экономическое развитие Китая и России}

Несмотря на то, что в настоящее время отношения между Китаем и Россией лучше, чем когда-либо в истории, а экономика и торговля между двумя государствами находятся на растущей стадии, экономическое и торговое развитие России и Китая по-прежнему имеет асимметрию и не соответствуют современным реалиям. У Китая и России есть проблемы в области инвестиций и торговли, такие как отсутствие унификации карантинных стандартов и ограничений на количество импорта и экспорта, что подчеркивает важность инициативы «Один пояс - один путь» для развития экономики и торговли между двумя сторонами. Мы полагаем, что инициатива «Один пояс - один путь» - это прекрасная историческая возможность для Китая и России осуществить сотрудничество по наращиванию потенциала в новых областях, таких как, например, китайская структурная реформа внутреннего подъема внут- 
реннего рынка или перепрофилирование производства в России, и при этом избежать участи превращения в «энергозависимые страны». Это имеет важное значение.

У Китая и России одинаковые задачи экономического развития: сотрудничество между двумя странами с точки зрения преимуществ потенциала и взаимодополняющих областей будет в большей степени способствовать формированию взаимопомощи и сотрудничества в экономической сфере в рамках инициативы «Один пояс - один путь» и поможет двум странам взаимовыгодно развиваться в экономическом ключе. Китай уже перешел на новый стандарт экономического развития: от быстрых темпов к стремительному росту, от расточительства к умеренности. Помимо этого, обоюдно сосуществуют вопросы «структурного регулирования, устойчивого роста и воплощения планов в реальность», поэтому Китай и Россия постоянно укрепляют сотрудничество в сфере строительства инфраструктуры.

Китай и Россия используют преимущества друг друга для снижения или устранения собственных недостатков: они являются не только «стабилизатором» для долгосрочного и устойчивого роста экономики, но и «регулятором» для содействия экономической перестройке и научно-техническому развитию. Вслед- ствие этого, эффективный способ для России в противостоянии серьезнейшим экономическим санкциям на Западе и успешном завершении внутренних экономических реформ - это стать активным участником инициативы «Один пояс один путь» и ориентироваться на сходства между «российской мечтой» и «китайской мечтой» [10]. Кроме того, необходимо серьезное содействие для воплощения в государствах идеалов «богатства, силы, демократии, просвещения, мира и красоты» как общей цели развития, укреплять новое экономическое строительство, обеспечивать экономический рост и устойчивое развитие двух стран за счет развития инфраструктуры.

В сентябре 2018 года председатель КНР Си Цзиньпин в своем выступлении в связи с 5-й годовщиной осуществления проекта «Один пояс - один путь» указал на следующее: ключевым моментом на современном этапе мира и развития является то, что Китай готов осуществлять глобальное управление проектом «Один пояс - один путь» вместе с другими странами, а также «готов плыть в бурю в одной лодке» («сообща преодолевать трудности» - пер. М.К.) [9]. Чувство социальной ответственности в Китае так же обозначает миссию Китая по внесению вклада в общее процветание и мировое развитие.

\section{Предложения о китайско-российском экономическом развитии в рамках инициативы «Один пояс - один путь»}

Как было указано ранее, в настоящий момент российско-китайские отношения находятся на высшей точке дружественного развития. Несмотря на то, что экономические отношения Китая с Россией находятся в состоянии баланса, а общий объем экономической торговли продолжает расти, мы полагаем, что инициатива «Один пояс - один путь» имеет еще больший потенциал для экономического развития России.

1. Развитие культурного обмена в гуманитарной сфере. Инициатива
«Один пояс - один путь» не только повлекла за собой значительный прогресс в китайско-российских политических отношениях, но и привела к развитию культурного обмена. Прежде всего, «Один пояс - один путь» открывает богатое многовековое культурное наследие и идеи мира, процветания, открытости, инноваций и культурного просвещения, дает развитие китайско-российской туристической индустрии. Россия не только занимает третье место в мире по количеству издательств, но и является крупнейшей страной-читате- 
лем. За последние десять лет российская издательская индустрия составляла около $65 \%$ структуры культурного экспорта, что в полной мере доказывает ее культурное преимущество на международной арене [2, с. 29]. В связи с выдвижением инициативы «Один пояс - один путь» Китай и Россия подписали совместное соглашение «Протокол о поправке к меморандуму о сотрудничестве России и Китая в области изданий и перевода классической и современной литературы» $[14$, с. 776$]$, в результате чего планируется открытие Российской академии искусств в Китае для содействия культурному обмену между Китаем и Россией. Наконец, углубленное сотрудничество между Китаем и Россией в области интеллектуальной собственности будет попрежнему способствовать плавному и гармоничному развитию китайско-российских отношений в области культуры.

2. Развитие российско-китайских экономических и торговых отношений посредством трансграничной интернет-торговли. По мере непрерывного развития науки и техники и воцарения эпохи Интернета отрасли промышленности, ком- пании и предприниматели все больше и больше предпочитают онлайн-торговлю. В связи с этим правительства Китая и России, a также трансграничные логистические компании делают все возможное для того, чтобы укрепить данную инфраструктуру и оказывают содействие для ее развития и перехода на новый качественный уровень, устраивающий представителей обоих государств [3, с. 100-105]. Две крупнейшие государственные логистические компании China Post и Почта России должны использовать прямые маршруты, организовывать транзитные склады, обеспечивать качественное обслуживание, поддерживать постоянный обмен информацией посредством информационных систем.

Таким образом, на фоне роста китайско-российских отношений проект «Один пояс - один путь» набирает обороты, отдавая приоритет развитию государственных предприятий, эффективно решая логистические задачи в соответствии с принципами мира, процветания, открытости, инновационности и гражданственности, способствуя развитию китайско-российских отношений в области экономики и торговли.

\section{Библиографический список}

1. Договор о добрососедстве, дружбе и сотрудничестве между Китаем и Россией [Электронный peсурс]: МИД России. URL.: http://www.mid.ru/ru/maps/cn/asset_publisher/WhKWb5DVBqKA/ content/id/576870 (дата обращения: 17.01.2019).

2. Книжный рынок России. Состояние, тенденции и перспективы развития. Отраслевой доклад / под общ. ред. В.В. Григорьева. - М.: Федеральное агентство по печати и массовым коммуникациям, 2018. - 88 с.

3. Король Р.Г., Демидова А.Е. Интеграция российской транспортно-логистической инфраструктуры в реализации нового шелкового пути «Один пояс - один путь» // Новые тенденции развития в управлении процессами перевозок, автоматике и инфокоммуникациях. Труды Всероссийской научно-практ. конф. ученых транспортных вузов, инженерных работников и представителей академической науки с международным участием/под. ред. А.И. Годяева. - Хабаровск: Дальневосточный государственный университет путей сообщения, 2017. - С. 100-105.

4. Кочергина T.E. От Таможенного к Евразийскому экономическому союзу: становление, функционирование, перспективы // Академический вестник. - 2015. - № 1(18). - С. 21-28.

5. Кушнарев B. Россия и Китай: кто кому нужнее [Электронный ресурс]: Информационноаналитическое агентство «Восток России». URL.: https://www.eastrussia.ru/material/rossiya-i-kitaykto-komu-nuzhnee/ (дата обращения: 17.01.2019).

6. Ли Синцай (李兴才). Исследование рыночного пространства инженерного строительства на территории стран-участников инициативы «Один пояс - один путь» (一带一路”沿线国家工程建设 市场空间与进入模式研究). Северо-Китайский энергетический университет (Пекин), 2017. - 24 с.

7. Ли Синь (李新). Шанхайская организация сотрудничества: важная платформа для строительства экономического пояса Шелкового пути (上海合作组织:共建丝绸之路经济带的重要平台). - Russian Journal, 2016. - № 6 (02). - C. 29-37. 
8. Ли Ян (李洋). «Один пояс - один путь»: выбор России (“一带一路”:俄罗斯的选择). - Цяньянь, 2018. - $240 \mathrm{c}$.

9. Рядом шагает новый Китай [Электронный ресурс]: Российская газета. URL.: РГ https://www.gazeta.ru/business/2014/05/21/6042673.shtml (дата обращения: 17.01.2019).

10. Си Цзиньпин. Связаться одной судьбой, единодушно развиваться (携手共命运, 同心促发展) // Жэньминь жибао. - 2018. - 4 сент.

11. Скрипарь М.В., Шамшурин Д.А. Инициатива «Один пояс и один путь» и концепция «китайская мечта»: точки соприкосновения // Актуальные проблемы гуманитарных и естественных наук. 2016. - № 9-1. - С. 267-269.

12. Соглашение между Правительством Российской Федерации и Правительством Китайской Народной Республики о культурном сотрудничестве [Электронный ресурс]: МИД России. URL.: http://www.mid.ru/foreign_policy/international_contracts/2_contract//storage-viewer/bilateral/page370/48731 (дата обращения: 17.01.2019).

13. Уянаев С. Китайский проект «Один пояс - один путь»: концепция, план, сотрудничество с Россией // Проблемы Дальнего Востока. - 2015. - № 4. - С. 8-21.

14. Цинь Шуизюань (秦淑娟), Лю Хуэй (刘慧), Сюй Симэй (翟喜妹). Развитие и регулирование китайско-российского культурного обмена посредством проекта «Один пояс - один путь» (中国与 俄罗斯文化贸易发展及对策). - Журнал Шеньянского университета (изд-во «Общественные науки»), 2017. - № 199 (06). - С. 776-782.

15. Чжан Ваньчунь (张万春). Анализ двусторонних договоров о культурных выставках нашего Китая (国文化领域会展双边条约解析) // Правоведение провинции Хэбей. - 2012. - № 30 (05). - С. 35-40.

16. Чжу Юй. «Один пояс, один путь» и китайско-российское торгово-экономическое сотрудничество // Проблемы Дальнего Востока. - 2016. - № 2. - С. 100-106.

\title{
THE ANALYSIS OF THE DEVELOPMENT OF THE SINO-RUSSIAN ECONOMY AND TRADE WITHIN THE BELT AND ROAD INITIATIVE
}

\author{
Li Hongyu \\ Institute of Marxism of the China University of Petroleum (Huadong)
}

The New Silk Road Economic Belt and the 21st Century Maritime Silk Road united under the short title «The Belt and Road» represent a collaborative project of the economic development of China and its neighboring countries which are at the same time its partners. While the global economy is improving, the Chinese economy is entering a new standard state, while the Russian economy currently demonstrates quite unbalanced economic structure.

This article analyses the positive impact of the Belt and Road initiative on the sustainable development of China and Russia in the sphere of economics, cultural exchange and trade (for example, transboundary e-commerce). It is noted that having chosen the Belt and Road initiative as a starting point, both parties should pursue common goals strengthening their economic cooperation on mutually beneficial conditions and achieve new development by making common efforts.

Keywords: The Belt and Road concept, China, Russia, economy and trade.

\section{Сведения об авторе}

Ли Хунъюй (李洪宇), Китайский нефтяной университет (Хуадун), Институт марксизма, докторант философии, г. Циндао, ул. Тхайханшаньлу, 30; e-mail: 292894857@qq.com 